\title{
COMMENTS ON THE ZONED CALC-SILICATE LENSES IN THE FREDERIKSHÅB AREA
}

\section{P. Brøgger Sørensen}

Lenses of zoned calc-silicate rock have been found in many places around Frederikshåb. They have been found not only in the migmatitic gneisses (cf. Walton, 1966) but recently also in unmigmatized hornblende schist layers.

In the gneisses the calc-silicate lenses occur as a minor constituent of thin, 2-10 $\mathrm{m}$ thick, horizons consisting dominantly of agmatitic inclusions of amphibolite. In most cases the calcsilicate lenses occur as a part of the agmatitic amphibolite. There is a variation in the size of the lenses, the small ones being $5-10 \mathrm{~cm}$ broad and $10-30 \mathrm{~cm}$ long and the large ones $30-40 \mathrm{~cm}$ broad and up to $1 \mathrm{~m}$ long. They are characterized by a more or less concentric zoning. From the rim to the centre of the lenses the following succession of zones is seen. The outermost zone (1) has an amphibolitic composition, consisting of hornblende and plagioclase, with a rather sharp boundary to zone (2) which consists of diopside, epidote and minor scapolite. This zone is characterized by the dominance of a green salitic diopside over epidote near the amphibolite zone and by the dominance of a clinozoisitic epidote over colourless diopside near the next zone, (3) the garnet zone. This zone consists of garnet with scattered crystals of scapolite, epidote and diopside. In the centre of the lenses calcite with some crystals of garnet and diopside are found. Sphene occurs as an accessory mineral in all zones. In the majority of the lenses the two innermost zones are lacking. They have therefore a greenish colour in contrast to the ideal lenses which are very characteristic with the reddishbrown garnet in the centre.

Layers in the thick unmigmatized hornblende schist horizons contain lenticular inclusions of a similar zoned calc-silicate rock. Here also most of the lenses are green due to epidote and diopside, 
but quite a few contain garnet and calcite in the centre. The same zoning as described above is found and although the lenses have not yet been studied in detail it is probable that the mineralogy is the same. The lenses make up less than fifty percent of the layers in which they are found, the bulk of the layer being ordinary hornblende schist as seen in the field. There is no evidence to suggest that the lenses are secondary structures such as boudins. It is therefore likely that the lens structure is of pre-metamorphic origin.

Because of the similarities in shape, mineralogy and rock association (hornblende schist and agmatitic amphibolite) it seems probable that the lenses found in the two different milieus are of the same origin. A difference between them is the coarser grain size in the lenses occurring in the gneisses.

It has been suggested (Walton, 1966, p. 38) that the lenses are relic pillow structures. The present author is not sure about the correctness of this suggestion, firstly because ordinary pillow lavas do not have as much groundmass as found here and secondly because of the peculiar composition of the lenses which in places contain a large quantity of calcite. One lens in gneiss, $25 \mathrm{~cm}$ broad and $50 \mathrm{~cm}$ long, consists almost entirely of salmon-pink-coloured calcite with scattered crystals of epidote, diopside and garnet.

Before further investigations have been made the present author thinks that suggestions concerning the origin of these zoned calc-silicate lenses should be limited to stating that they represent remnants of calcium-rich rocks in the original material, the lens structure being of pre-metamorphic origin.

\section{Reference}

Walton, B.J. (1966) The relationship between relic pillow structures and zoned calc-silicate skarns, and the significance of talc balls in gneisses south of Frederikshåb. Rapp. Grфnlands geol. Unders. , Nr. 11, 38-39. 